\title{
Univerzitní basketbal v kontextu globalizace sportu
}

\section{College basketball in sport globalization}

\author{
Aleš Sekot, Tomáš Pětivlas \\ Fakulta sportovních studií Masarykovy univerzity v Brně
}

\begin{abstract}
Abstrakt
K významným rysům soudobého vrcholového výkonnostniho sportu a sportu obecně patři jeho globalizačni povaha. Dnešní postavení zejména elitního sportu v světovém kontextu je navíc stále zřetelněji modelováno s globalizaci těsně spjatou sportovní migrací, založenou na procesu hledání co nejvýhodnějšiho postavení na scénè sportu nejenom v rámci jednotlivých zemí, ale i kontinentù. Systém globální sportovni migrace ve svých di̊sledcích působí nejen na samotné sportovce, ale i na hostujicí a „dárcovské “ zemé, sportovní ligy, soutěže a na sport samotný. A v př́padě každého subjektu existují jak pozitivní, tak i stinné stránky, neodolatelné perspektivy i zklamání. Nejlepši basketbalovi hráči světa tak přicházeji do americké NBA, která využivá zahraničnich talentů, do prostředi nejvyšši soutěžni kvality budované v tvrdém konkurenčním prostředi. Přitom není pochyb, že právě americký vrcholový basketbal významně akceleroval globalizaci na půdě sportu: jednak mediální popularitou, a zejména pak sportovni mobilitou na pi̊dě vrcholových ligových soutěži. Jednou z možností pro evropské hráče, jak být součástí tohoto atraktivního kariérního systému, je stát se v rámci studia na některé z amerických vysokých škol hráčem univerzitní americké soutěže NCAA (National Collegiate Athletic Association). Tato jedinečná přiležitost byla v letošním roce nabidnuta i dvěma brněnským odchovancům, kteři tak dostali na základě př́sného výběru možnost věnovat se v souladu s principy amatérizmu zároveň studiu i vrcholovému sportu.
\end{abstract}

\section{Abstract}

The most important feature of contemporary top performance sport, as well as sport in general, is globalization. Its natural reflection, the system of global-sport labor migration exists; consequences are not only for the sport workers themselves but also for the host a donor nations, sport leagues and teams, and for the sport itself. For each there are positive effects and benefits, but there are also disappointments and drawbacks as well. A core question in ascertaining the reach and response of globalization in sport from the perspective of basketball is that of sport migration: The best basketball players in the world go to play in the United States NBA. Teams bring in immigrant athletes to gain a competitive edge over their competition who are almost exclusively relying on national, or home grown talent. One of the exclusive chance for European players to be part of such attractive system of sport carrer is to study at some US university and play in basketball team organized by National Collegiate Athletic Association. Such excellent oportunity are just taken advantage also for two young basketball players from Brno, passing strictly demanding selection for the chance to be part amateur top basketball league NCAA and study at American universities, too.

Klíčová slova: globalizace, sport, studium, basketbal, skauting, amatérismus

Key words: globalization, sport, study, basketball, scauting, amateurism

\section{Globalizační rámec sportovní migrace}

Vynikající bojovník proti apartheidu a bývalý boxer Nelson Mandela prohlásil: „Sport je zřejmě nejúčinnějším prostředkem komunikace moderního světa, a to nad rámec verbální a psané komunikace, když př́mo zasahuje miliardy lidí na celém světě. Není pochyb o tom, že sport je viditelnou a legitimní cestou budování přátelství mezi národy (Maguire, 2005, p. 1). 
Sport je vnímán jako progresivní a liberální fenomén otevírající nebývalé možnosti pro lidské kontakty, dialog a př́telství. Globální sportovní události typu olympijských her jsou tak hodnoceny jako prostředek podpory lidských práv, demokracie a interkulturního porozumění. Přitom jsou šířeny hodnotové důrazy typu naděje, sny, aspirace, přátelství, fair play a radost z překonávání překážek na cestě k sebezdokonalení. Tím, že se národy cestou identifikace se sportovními symboly vymezují vůči okolnímu světu, stávají se viditelnějšími a sebevědomějšími. Sport na národní úrovni tak v době globalizace nachází vlastní cesty své reflexe zejména tím, že spojuje lidi a ideje na místní a regionální úrovni.

Soudobé postavení zejména elitního sportu v globálním kontextu je stále zřetelněji modelováno sociologicky zaznamenáníhodným a sociálně politicky důležitým procesem pracovní migrace (Maguire, 2002). Tento proces se týká primárně sportovců, ale zahrnuje i trenéry, funkcionáře, manažery a sportovní teoretiky. Jde o proces hledání co nejvýhodnějšího postavení na scéně sportu nejenom v rámci jednotlivých zemí, ale i kontinentů. $\mathrm{V}$ devadesátých letech byly tak z hlediska sportovní migrace $\mathrm{v}$ centru pozornosti sociologů zejména některé sporty, jako fotbal (C. Bromberger, P. Lanfranchi, J. Maguire, R. Pearton, D. Stead), lední hokej (J. Maguire), baseball (A. M. Klein), basketbal (J. Maguire). Ústředním tématem bývá v tomto ohledu zpravidla zkoumání základních zdrojů a směřování a geografické cílenosti sportovní migrace a její dopady na „hosty“ a „hostitele“. Již vzhledem k intenzitě sportovní migrace lze konstatovat, že její zdroje jsou hluboce zakořeněny v globalizačních procesech poslední dekády dynamicky a rozhodně i rozporuplně se rozvíjející sportovní scény.

Nikoli pouze z informativního hlediska je užitečné položit si v tomto ohledu některé zřejmě až v blízké budoucnosti uspokojivě zodpověditelné otázky:

- Které sporty a z jakých důvodů jsou migrací nejvíce poznamenány?

- K Kakým strukturálním či kulturním změnám v takovýchto sportovních odvětvích dochází?

- Existují obecně fungující vzory globální migrace?

- Jak se migrace sportovců projevuje ve výchozích a hostitelských zemích?

- Které jsou hlavní motivy sportovní migrace?

- Jaká je nejčastější typická osobní zkušenost sportovců v hostitelských zemích?

Pro motivy sportovní migrace sehrává významnou úlohu i komplex předpokladů sportovního úspěchu. Ten závisí na souboru několika $\mathrm{v}$ různém kontextu nestejně působících předpokladů, které byly správně identifikovány již počátkem sedmdesátých let:

- dostupnost lidských a materiálních zdrojů,

- vědecké metody koučování a tréninku,

- $\quad$ kvalita sportovních organizací a hluboké znalosti sportovního lékařství a věd o sportu.

$\mathrm{K}$ těmto globálně působícím principům však na lokální úrovni přistupuje i význam národa či státu na mezinárodním sportovním poli a jeho schopnost účinně vyhledávat a využívat talentované jedince specifických genetických kvalit. V tomto kontextu se silně aktualizuje i sportovní příprava na půdě vzdělávacích zařízení, především možnosti rozvoje sportovních atletických a basketbalových talentů na americké univerzitní půdě.

Přitom si musíme opakovaně připomínat, že kontrola ekonomických zdrojů, směřování a ideového působení je stále v rukou Západu, který i zde figuruje jako rozhodující, respektovaný a prestižní činitel globálního směřování sportu. Zejména do USA směřují sportovní talenty z celého světa. Západ navíc rozhoduje i o designu, výrobě a marketingové strategii sportovních produktů, důležité sportovní organizace jsou převážně ovládány západními představiteli.

Obecně k největším migračním posunům dochází na půdě sportů jako jsou kopaná, lední hokej, basketbal, kriket a nověji i lehká atletika. Z pohledu české sportovní scény je tak zcela běžné sportovní angažmá na mezinárodní úrovni zejména díky působení českých fotbalistů v prestižních evropských klubech (dále i odbíjenkářů, hokejistů aj.), a to hráčů i trenérů. Interkontinentální sportovní migrace se ze zorného úhlu českých sportovců saturuje zejména díky častým př́ípadům angažmá hokejistů v kanadsko-americké NHL či na scéně amerického basketbalu. Stejný v zásadě jednosměrný migrační trend existuje kupř́ikladu mezi dominikánskými basketbalisty působícími v USA. Zřetelně ekonomicky podmíněnou sportovní migraci, nám známý „exodus“ řady vynikajících sportovců z bývalých zemí socialistického bloku na Západ, lze ilustrovat jako jisté a v jiném kontextu všeobecně známé „,vykrádání mozkư“. Je nepochybné, že rozšiřrení Evropské unie směrem na východ tento trend posílí.

\section{K motivům sportovní migrace}

K největší akceleraci sportovní migrace dochází ve sportech, jako je americká kopaná, baseball, basketbal 
a lední hokej. Zde jsou zřetelné zejména sílící obousměrné pohyby mezi Severní Amerikou, Evropou, Jižní Amerikou a Asií. V polovině devadesátých let tak v Evropě - jmenovitě zejména v Itálii a Španělsku - působilo kolem čtyř set amerických profesionálních basketbalistů. Hokejisté z USA a Kanady využivají své profesionální dovednosti v Británii, Německu, Francii a Švýcarsku; zatímco americké hokejové kluby usilují o získání špičkových hráčů ze Skandinávie, České republiky, Slovenska či Ruska. Americké univerzity v Evropě a nověji i v Africe vyhledávají zejména talentované atlety, fotbalisty, hráče rugby, basketbalisty a plavce (Bale and Maguire, 1994, p. 37-50). Na nejen geograficky vzdálené britské kriketové scéně působí stále rostoucí počet hráčů z Austrálie, oblasti Karibiku, jižní Asie a Jižní Afriky. Zde však, stejně jako v př́ípadě rugby, má sportovní migrace spíše sezónní charakter. Klimatické rozdíly mezi severní a jižní hemisférou totiž dovolují během roku sehrát dvě sezóny (Maguire, 2002, p. 26-44; Yiannakis and Melnick, 2001, p. 447-467).

Rostoucí zájem sociologie přitahuje dnes sportovní angažovanost amerických hráčů na britské basketbalové scéně. Na základě dvouletého etnografického projektu, využívajícího metody pozorování a rozhovorů, byl konstatován socializační význam konfrontace migrantůs místním patriotismem, kulturními stereotypy a specifiky divácké odezvy. Sílící př́liv amerických basketbalistů je silně ovlivňován častým působením Američanů $\mathrm{v}$ trenérských postech $\mathrm{v}$ Británii, kteří přirozeně rádi dávají hráčskou př́íležitost svým krajanům. Tím se také postupně mění i celkový místní hráčský styl a divácká odezva. Přitom je typické, že zatímco američtí hráči během svého působení v Británii vystř́ídají i několik týmů, nejlepší britští basketbalisté působí na evropském kontinentu či v USA. To přirozeně přináší i nebezpečí přehlížení místních talentovaných hráčủ. Přitom se sváří na jedné straně divácké fandovství vůči místnímu týmu, rivalita vůči konkurenčním týmům, touha po klubovém úspěchu a hodnotném diváckém zážitku, na druhé straně přirozený patriotismus spojovaný s preferencí místních sportovních hvězd. Fenomén hráčské a divácké identity pak v tomto kontextu přináší zajímavý rasový obraz: Hráčské kádry tvoří převážně američtí a britští černoši, zatímco divácké řady jsou naplňovány většinou bělochy středních sociálních vrstev. V představách diváků jsou pak imigranti považováni za ekonomické prospěcháře neosobních vztahů k místu působení, zatímco lokálním hráčům je přisuzován hluboký osobní vztah k městu a $\mathrm{k}$ mateřskému týmu (Maguire and Falcous, 2005, p. 23-40).

Zvláštní pozornost $\mathrm{k}$ sobě nepochybně váže i reakce migrujících sportovců. Neustálý pohyb tam a zpět mezi různým kulturním prostředím vyžaduje vysokou míru flexibility, sebeovládání, předpoklady k rychlé orientaci a adekvátní reakci na změnu prostředí. Těmto tlakům nečelí sportovní migranti stejně; pro někoho jde spíše o osobní výzvu, která se zdá být spíše zábavnou, pro jiné naopak interkulturní komunikace může znamenat opakující se stresující záležitost.

Na pozadí mnohorozměrné scény protichůdně působících procesů sportovní migrace tak působí jak pozitivní, tak negativní jevy, rozporuplně nazírané z pozic výchozí i hostitelské země.

Podpůrné argumenty a motivy pro globální sportovní migraci se tak opírají o:

- Revitalizaci domácího sportu,

- Z Zvýšení atraktivity sportovní podívané prezentací nových osobností a herních stylů,

- $\quad$ diváckou př́ležitost vidět opravdu ty nejlepší hráče,

- Zvýšení klubového členství a divácké návštěvnosti,

- Posílení zájmu sponzorů a médií,

- Konfrontační výzvu pro domácí hráče,

- Posílení prestiže klubových soutěží a reprezentace hostitelské země, prrístup k talentům v případě nedostatku domácího dorostu (Maguire and Stead, 2005, p. 74).

Naopak konfrontační názory vyvolává suma problémů spojených s výhradami týkajícími se:

- U Úbytku příležitostí pro domácí náročně sportovně připravované hráče, zejména v určitých herních pozicích.

- Snížení kvality a kreditu národního týmu, zejména kapitánské pozice.

- Nesouhlasu s apriorním přesvědčením o lepší kvalitě příchozích hráčů ve srovnání s domácí hráčskou základnou.

- $\quad$ Obavy z eroze tradičního ducha, étosu a etiky anglického sportu (Maguire and Stead, 2005, p. 75).

Nepřehlédnutelné postupné vyprazdňování nejlepších či talentovaných nadějí sportu ve výchozích zemích postupně vyvolává obavy z možných důsledků této spíše jednosměrné formy profesní migrace. Zatímco chudé 
země vítají kariérní příležitosti svých migrujících sportovců, bohatší země zvažují spíše ekonomické, lidské či kulturní ztráty. Aktualizuje se také problematika motivů sportovní migrace, když vedle zřejmě obecně dominujících finančních a prestižních důvodů pro sportovce z bohatších zemí přistupují motivy typu: osvojit si nové profesní zkušenosti, docílit mistrovský herní styl, ověřit si svůj talent ve vysoce kompetitivním prostředí, získat nové životní obzory a kariérní perspektivy. V řadě případů jde nepochybně o př́nos pro „obě strany“, jinde je skóre př́nosu a újmy, zisku a ztráty sporné či jednostranně vychýlené.

Zastánci neomezeného př́livu sportovní migrace, jako kupříkladu vlastníci velkých fotbalových klubů, zpravidla horují pro sportovní migraci s cílem přitáhnout pozornost diváků co nejlepšími výkony mezinárodně známých sportovních hvězd. Ve světě sportu je pak známo spíše účelové tvrzení sportovního podnikatele, mediálního magnáta a krajně kontroverzního italského politika Silvia Berlusconiho, který v této souvislosti tvrdí, že se původní smysl národních týmu s postupnou globalizací světa vyprazdňuje a že se naopak posiluje fandovství na místní úrovni. Sportovní úspěch národních týmů tak z tohoto jistě alarmujícího pohledu je druhořadou záležitostí. To na čem prý opravdu záleží, je klubový úspěch. Existence a sílící popularita fotbalové Ligy mistrů je nepochybně konkrétním výrazem tohoto procesu, migrace sportovní pracovní síly je jeho integrální součástí. Přitom vyhodnocení dlouhodobého dopadu této stránky soudobého vrcholového elitního sportu nás teprve čeká. Nepochybně může jít o jedinečný prŕíspěvek do stále aktualizovaných problémů interkulturní komunikace a multikulturní koexistence (Sekot, 2006, p. 171-200).

\section{Sportovní migrace: př́ípad basketbalu}

Nesmírně zajímavým př́spěvkem k tématu sportovní migrace na půdě basketbalu je disertační práce americkoho doktoranda Williema Crossana „Sporting immigrants and their effect on sport popularity in a culture: The case in Czech basketball“ (2012). (V překladu Sportovní imigranti a jejich vliv na rozvoj popularity ve společnosti. Studie českého basketbalu) zabývající se hodnocením působení zahraničních hráčů v české vrcholové basketbalové soutěži MNBL ze zorného úhlu základních hybných sil sportovní globalizace. Připomeňme na tomto místě Jiřího Welsche, který v opačném proudu sportovní migrace na přelomu naší dekády na půdě basketbalu „otevřel dvěře“ do americké NBA. Vedle tohoto našeho vynikajícího hráče to po roce 2002 platí kupřs. i o čínské basketbalové hvězdě Yao Mingovi. Ve stejné době působilo v naší nejvyšší basketbalové soutěži 29 zahraničních borců především z USA a zemí bývalé Jugoslávie.

Řada studií nalézá prímou úměru mezi působením zahraničních atletů v NBA a růstem úrovně a popularity basketbalu v jejich domovských zemích (Cronin, Doyle, \& O'Callaghan, 2008; Goldiner, 2003; Larmer, 2005). Tuto tendenci podporuje i působení zahraničních hráčů v zemích rozvíjející se popularity basketbalu v rámci Evropy. Nejvíce zahraničních basketbalistů působilo v polovině minulé dekády v Německu, Španělsku a Itálii (65-71 \%); nejvyšším podílem amerických hráčů basketbalu na sebe upozornila Velká Británie (74 \%); 62\% zastoupení amerických basketbalistů vykázalo Holandsko. Naopak na americké basketbalové scéně počátkem devadesátých let na půdě NBA působilo pouze dvacet zahraničních hráčů; jejich počet v polovině devadesátých let dosáhl čísla 68 a v roce 2008 působilo v této prestižní soutěži 75 hráčů z 32 zemí .

Český basketbal představuje na globální úrovni spíše okrajovou zemi, která přijímá sportovní migranty jak ze zemí obdobné basketbalové tradice a úrovně (kupř. Polsko a Slovensko), tak z baskebalových velmocí (Spojené státy, země bývalé Jugoslávie). V současnosti se podíl zahraničních hráčů z desítky na konci minulého století ve vrcholové Mattoni NBL zvýšil na současných cca pět desítek. K nejsilněji deklarovaným motivacím působení zahraničních hráčů basketbalu v našich podmínkách patří hodnota kompetitivní výhody spojená s možností hrát i po zenitu osobní sportovní výkonnosti ve vrcholové soutěži; pro mladší hráče hraje v tomto ohledu dominantní význam získat zahraniční zkušenosti jako základ budoucí kariéry. Významnou motivací českých koučů pro angažování zahraničních basketbalistů je nedostatek kvalitních českých hráčů, možnost zejména pro mladé české hráče získat jedinečné zkušenosti od zahraničních basketbalistů a v neposlední řadě i zvýšení divácké atraktivity této stále populárnější akční kontaktní hry, především ve snaze získat skórující a týmově takticky hrající basketbalisty. Trenáři oceňuji při výběru zahraničních hráčů profesionalní př́istup, kolektivní duch a př́kladnost $\mathrm{v}$ plnění očekávaných herních rolí. Nepřehlédnutelné hledisko divácké atraktivnosti zpravidla upřednostňuje barevné hráče před bílými (Crossan, 2012). Stejný zdroj na základě výzkumu zkušeností koučů našich vrcholových baskebalových týmů uvádí, že vzdor přinejmenším dočasné výhodě angažmá zahraničních basketbalistů je nejsmysluplnější dlouhodobou investicí výchova domácích talentovaných hráčů.

Crossan (2012) ve své jedinečné práci dále shrnuje podstatné současné tendence českého basketbalu při 
výběru zahraničních hráčů:

- Přesun zájmu od hráčů bývalé Jugoslávie směrem k americkým basketbalistům.

- $\quad$ Rostoucí zájem o barevné hráče.

- Slábnoucí atraktivnost absolventů amerického univerzitního sportu a posun směrem k vyššímu zájmu o vyzrálé hráče s dlouhodobější zkušeností v evropských ligových soutěžích.

- Působení zahraničních hráčů zlepšuje postavení týmů v ligové soutěži.

- Př́tomnost zahraničních hráčů zprostředkovaně posiluje společenské klima interkulkturní koexistence, tolerance a hodnotové plurality.

Není pochyb o tom, že právě americký vrcholový basketbal významně akceleroval globalizaci na půdě sportu: jednak mediální popularitou a zejména pak sportovní mobilitou na půdě vrcholových ligových soutěží. Legendární NBA k sobě přitahuje nejlepší hráče světa, umožňuje jejich účínkování v atraktivních ligových soutěžích, a zvyšuje tak mediální přitažlivost basketbalu v globálním měřítku. Tento fenomén se dostává stále více do hledáčku sociologických výzkumů sportovní migrace, stejně tak se zvyšuje zájem masových médií jak o sport samotný, tak o jedinečné kariéry cizích hráčů zejména ze Spojených států amerických. Nejlepší hráči světa tak opouštějí svoje domovské kluby ve snaze získat v atraktivním zahraničním angažmá vysokou finanční odměnu, lepší treninkové možnosti, mimořádnou př́ležitost sportovního růstu a jedinečnou půdu k budování neopakovatelného klimatu obdivu a slávy. Nejen př́klad Jiřího Welsche akceleroval odliv českých hráčů do řady zemí, kde se jejich počet dnes pohybuje kolem stovky; vedle sousedních zemí jako Německo, Rakousko a Polsko směřuje stále víc basketbalistů do Španělska a Itálie. Nelze vyčíslit či přesněji popsat ztráty či naopak zisky (kontakty, medializace sportu, tréninkové možnosti, interkulturní setkávání), které vznikají českému basketbalu ztrátou talentovaných vyzrálých hráčů; jisté však je, že samotný proces sportovní mobility na tomto poli zvyšuje poplaritu basketbalu jednak jako divácké formy masové kultury, jednak jako preferovaný organizovaný aktivní sport mládeže.

\section{Sportovní migrace: Možnosti přechodu evropských hráčů basketbalu do National Collegiate Athletic Association}

Snad nejčastějším snem organizovaného basketbalisty je možnost být aktivní součástí zrrejmě nejsledovanější soutěže světa - americké NBA. Jednou z možností pro evropské hráče, jak tento sen naplnit, je stát se v rámci studia na některé z amerických univerzit hráčem univerzitní americké soutěže NCAA (National Collegiate Athletic Association). Tato jedinečná př́ležitost byla v roce 2013 nabídnuta i dvěma brněnským odchovancům trenéra Tomáše Pětivlase. Marek Souček se vypravil do Okhlahoma State a Patrik Auda se seznámil s univerzitním basketbalem v Seton Hall. Tomu po maturitě obou borců předcházel pobyt na španělské basketbalové akademii na Kanárských ostrovech (CBA, soukromá škola), do které byli vybráni na základě předchozí desetidenní stáže. Zde obdrželi roční stipendium a možnost startovat na prestižním turnaji v USA, kde si skauti jednotlivých univerzit vybírají hráče do svých týmů.

National Collegiate Athletic Association (Národní vysokoškolská atletická asociace) je polodobrovolný svaz 1281 institucí, konferencí, organizací a jednotlivců, organizujících sportovní programy mnoha vysokých škol a univerzit ve Spojených státech a Kanadě. Její sídlo je v Indianapolis v americkém státě Indiana.

V sedmdesátých letech minulého století byla $\mathrm{v}$ rámci tří divizí této asiciace dohodnuta pravidla možností a mezí nabídek sportovních programů a stipendií pro hráče přibližně tisícovky univerzitních týmů.

Divize I. je povinna nabízet alespoň 14 sportů (sedm pro muže a sedm pro ženy, nebo šest pro muže a osm pro ženy). Vysoká škola se musí účastnit podzimní, zimní a jarní části sezóny. Dále je zde povinnost vysokých škol nabídnout určitý počet finančních podpor pro studenty-sportovce a nepřekročit jejich maximální povolenou částku. Divize II. je povinna nabízet pouze 10 sportů (alespoň 5 pro muže a 5 pro ženy nebo 4 pro muže a 6 pro ženy). Vysoká škola musí dotovat alespoň dva týmy žen a mužů. Stejně jako v divizi I. se vysoká škola musí účastnit podzimní, zimní a jarní části sezóny.

Legislativní a organizační struktura rozděluje NCAA do kabinetů a výborů, sestávajících ze zástupců jednotlivých členských škol. Ty mohou být dále členěny na podvýbory. Legislativa je předávána ke kontrole správní radě, která dohlíží na všechny kabinety a výbory. Také zahrnuje zástupce škol, jako jsou sportovní ředitelé a fakultní poradci. Hierarchie managementu vrcholí představenstvem, které se skládá z prezidentů škol, jako orgánem pro schvalování legislativních návrhů. 
Součástí legislativní organizace NCAA jsou následující sporty: basketbal, baseball (muži), softball (ženy), americký fotbal (muži), atletika, pozemní hokej (ženy), bowling (ženy), golf, šerm, lacrosse, fotbal, gymnastika, veslování (ženy), volej-bal, lední hokej, vodní pólo, střelba z pušky, tenis, lyžování, track, plavání a potápění, zápas (muži). (Zdroj: http://cs.wikipedia.org/)

Systém NCAA dovoluje sportovcům věnovat se studiu i vrcholovému sportu zároveň. Obdobný systém je znám i v Japonsku. Hlavním krédem této jedinečné organizace sportovní a studijní př́pravy je princip amatérismu. Hráči tak za své výkony nejsou finančně odměňováni; odměnou je tak vedle stipendia týmové oblečení a respekt od spolužáků a sportovních diváků. Svět amerického univerzitního sportu s hvězdným étosem vynikajících sportovních výkonů má i své stinné stránky, a to především v podobě bujícího elitářství a upřednostňování sportovnícho úspěchu nad studijním úsilím (Coakley, 2001). Nepřehlédnutelně působí americké varování z poloviny minulé dekády: „Vysokoškolský sport na nejvyšší úrovni se stává příliš velkým, je ovládaný pěnezi a podnikatelskými zájmy, kterým univerzity zpravidla podléhají.“ (Eitzen et al, p. 229).

NCAA, národní asociace podporující vysokoškolský sport, funguje podle přísných pravidel amatérismu. Počínaje omezeními mediální prezentace hráčů či absencí institutu sportovních agentů. Klima amatérismu ilustruje kupř. př́pad Enese Kantera, který byl tvrdě sankcionován za prokázaný dřívější smluvní profesionální vztah. Tato přísná prvidla se však netýkají trenérů, jejichž příjem během dlouhodobých kotraktů činí i desítky milionů dolarů.

Vysokoškolský sport je vysoce populární jak mezi studenty, tak přitahuje divácký zájem absolventů škol zapojených do sítě NCAA. V souladu s atraktivitou jednotlivých sportů na konkrétní vysokoškolské fakultě počet diváků zpravidla osciluje mezi několika stovkami až několika tisíci. Z našeho pohledu spíše nezvyklým principem je zdejší systém kvót, stanovujících určitý počet zápasů hraných na neutrální půdě. Není proto překvapující, že zejména $\mathrm{v}$ první polovině sezóny jsou organizovány turnaje $\mathrm{v}$ místech, kde ani jeden tým nesídlí. To umožňuje hráčům strávit určitý čas v atraktivních destinacích jako jsou Bahamy, Havaj či Panenské ostrovy. Navíc zpravidla jednou za čtyři roky tým vyjíždí na letní herní soustředění do Evropy. Počet dnů a zápasů je ale opět limitován regulemi organizace NCAA.

\section{Univerzitní basketbal}

Univerzitní mistrovství USA v basketbalu se hraje ve třech divizích a působí v nich na 970 vysokých škol. To představuje přibližně osmnáct tisíc hráčů. Od března hraje nejlepších 68 týmů první divize turnaj vylučovacím způsobem na jednu porážku (osm škol z menších konferencí hraje předkolo a samotného turnaje se účastní 64 týmů). Čtyři nejlepší týmy se střetnou ve finále. Play-off se hraje na jedno utkání, vždy na neutrálním hřišti, které musí být více než 300 km od sídla příslušných škol. Teprve závěr turnaje se hraje na jednom místě. Popularitu univerzitního basketbalu dokazuje již skutečnost, že „Final Four“ - finále čtyř nejlepších týmů - se koná v hale pro minimálně 70000 diváků!

O popularitě univerzitního basketbalu v USA svědčí také skutečnost, že v roce 1994 zakoupila televizní stanice CBS práva na finále NCAA do roku 2002 za neuvěřitelných 1,725 miliardy dolarů. Tato i na americké poměry obrovská investice přispěla k masové divácké popularitě této sportovní akce, která přes svůj amatérský charakter patř̌i k mediálně nejsledovanějším sportovním akcím. Je pochopitelné, že z hráčské osmnáctitisícové amatérské základny NCAA se každoročně do čistě profesionální NBA prosadí asi jen čtyři desítky hráčů.

Nejúspěšnějším týmem v historii amerického vysokoškolského basketbalu je kalifornská UCLA, která se pyšní jedenácti tituly. Bez zajímavosti není skutečnost, že v roce 1995 pomohl vybojovat vysoce ceněný titul vítěze Final Four i zatím jediný český šampion NCAA Jiří Zídek. Specifika této jedinečné soutěže spočívají i v odlišnosti herních pravidel; např. dva poločasy, odlišné vyznačení hrací plochy, 35vteřinový limit pro střelbu na koš (viz http://basket.idnes.cz/).

\section{Specifika tréninkového cyklu na půdě NCAA}

Zvláštností oplývá soutěž NSAA i z pohledu tréninkového cyklu. V univerzitní soutěži USA v basketbalu mužů začíná příprava na sezonu zhruba dva týdny po skončení předchozích vyřazovacích bojů, tedy v polovině dubna. Pro trenéry univerzity jde o velmi důležité období kontaktu s hráči cestou tzv. „recruitingu“, selektujícího perspektivní hráče, kteří mají předpoklady stát během studia týmovou součástí. Tato tréninková fáze umožňuje pracovat se 100 až 150 hráči, kteři mohou být v užším hledáčku trenéra až od třetího ročníku studia střední 
školy. Přitom platí nepřekročitelná pravidla kontaktu s oslovenými hráči, jako je určení limitu SMS, telefonních hovorů či přesně dohodnutých osobních návštěv. Silnou motivací ze strany potencionálních frekventantů programu soutěže NSAA jsou vedle sportovní a studijní prestiže vysoké školy i podmínky, které pro soutěžní basketbal poskytuje: úroveň sportovních zařízení, zejména hala a šatna, kvalita stravy, úroveň ubytování, kvalita sportovní výbavy. K nepřehlédnutelným motivům hráčů Oklahoma State tak patří kupř. luxusní šatna vybudovaná za 4 miliony dolarů a nabízející vedle kožených sedaček i kulečníkový stůl, pinball videohry či šest obřích televizorů. Potencionální zájemci o studium a hráčskou pozici na půdě NSAA absolvují v sezóně tzv. official visit, seznámení s prostředím vysoké školy omezené na dobu 48 hodin, většinou u př́iležitosti domácího utkání či po ukončení předchozí sezóny. Skautovaní hráči tráví střídavě čas s trenéry i s hráči, někteří jsou zapojeni i do hry 5 proti 5 .

Univerzitní hráči se mohou v tomto období připravovat basketbalově pouze individuálním tréninkem ve třech tréninkových jednotkách týdně, k tomu mohou využít tzv. OPENGYM - tři 60 minutové tréninky $5 / 5$, ale bez možnosti zapojení trenérů do utkání. Hráči ještě využívají čtyřikrát týdně posilovnu, která je zaměřena následovně: posilování svalstva rukou a trupu, druhý den následně posilování svalstva nohou, třetí den volno, čtvrtý a pátý den opět střídavě nohy-ruce, šestý a sedmý den volno. Hráči tak trénují do srpna, kdy obdrží třítýdenní volno.

K 1.10. pak hráči mohou týdně absolvovat s týmem 6 kondičních jednotek a denně 120 minut basketbalu; z toho ale pouze jeden trénink je týmového charakteru. Od 1. 10. jsou tréninky omezeny na 20 hodin týdně. Od konce října do března trvá hlavní část basketbalové sezóny. Hráči absolvují 2,5 hodinový basketbalový trénink jednou denně, k tomu opět posilovna (v soutěži hráči dochází již jen dvakrát týdně). Časově je trénink navázán většinou na školu. Např. na Seton Hall, současné škole P. Audy a bývalé škole L. Sanderse, je zvykem trénovat od 15 do 17 hodin. Škola trvá od pondělí do čtvrtku a rozvrh končí v 14,15. Studenti si zapisují povinné a volitelné předměty podobným systémem jako u nás, plní 15 kreditů za semestr, tedy 30 za rok a 120 za studium. Předměty jsou většinou tř́kreditové, takže studenti si zapisují přibližně 5-6 předmětů v semestru.

V dopoledních hodinách mají hráči ve volném čase posilovnu a střelecké tréninky. Trenéři pracují s rozvrhy hráčů a jsou jim v posilovně i v hale $\mathrm{k}$ dispozici pro individuální trénink či cvičení. Na škole si lze vybrat studijní obor: P.Auda studuje napřr. ekonomii a finance, $\mathrm{k}$ tomu si přidal ještě ruský jazyk. Každý tým má 12 stipendijních míst, tedy 12 hráčů, ale počet hráčů bývá zpravidla navýšen o 3 až 4 hráče, kteří trénují s týmem, ale nepobírají stipendium. Výší stipendia školy liší, přibližně se částky pohybují kolem 50000 USD za rok. Částka zahrnuje náklady na školné, ubytování, jídlo a studijní literaturu. Američtí hráči ještě obdrží kapesné, které je odvozeno od př́ijmu rodičůn, takže sociálně slabší studenti jej mají kolem 4000 USD ročně. Evropané dostávají pouze př́spěvky na stravu při výjezdech na utkání (20 USD/ den) a při domácích utkáních (15 USD) nebo v př́ípadě vánočních prázdnin, kdy nefunguje školská menza (cca 800 USD). Hráči nedostávají prémie za vyhraná utkání.

Kromě studia a samotných tréninků hráči absolvují i rozsáhlý rozbor každého soupeře, s kterým se utkají. Na univerzitě Oklahoma State první skauting začíná tři dny před utkáním, Na něm hráči shlédnou video a dostanou informace o hráčích soupeře. Každý hráč soupeře je představen na videu v asi deseti typických akcích a uvedena statistika jeho herní úspěšnosti. Dva dny před utkáním je projekce dalšího třicetiminutového videa, které je zaměřeno na typické akce soupeře, jeho protiútok, ukázku typických variant při vyhazování za koncovou a postranní čarou. Na dopoledním tréninku po dobu cca 45 minut trenéři určují obranu jednotlivých akcí. Často využívají pětici méně využivaných hráčů, kteří představují soupeře. Přri venkovním utkání následuje odpoledne let do místa utkání. Večer je připraveno 30minutové video - rozbor akcí soupeře z jiných utkání. Součástí večera je př́íprava hráčů podle vytištěného materiálu s detailní analýzou soupeře. Obsahuje rozbor hráčů, statistiky, rozbor akcí. Po videu následuje pratktické seznámení se soupeřem na hřišti.

$\mathrm{V}$ den zápasu je dopoledne umožněno trénovat $\mathrm{v}$ hale, kde se koná utkání. Trénink je zaměřen na akce týmu, které jsou prováděny bez obrany (5/0). Z akcí soupeře se rozebírá pouze vyhazování ze zámezí. Zbytek času je věnován individuálnímu tréninku podle jednotlivých postů a střelbě.

Součástí univerzitního týmu jsou vedle hlavního trenéra tři asistenti, každý z nich je odlišně zaměřen (obranné kombinace a systémy, útočné kombinace a systémy, trénink pivotmanů). Dále je v týmu kondiční trenér, dva video statistici, statistik tréninkové jednotky, jeden hlavní fyzioterapeut se dvěma asistenty (studenty fyzioterapie), kteří plní i funkci masérů a zajišt'ují pitný a stravovací režim družstva. Každého tréninku se účastní 6-8 pomocníků z řad studentů, kteří podávají hráčům míče, utírají podlahu, poskytnou ručník atd. 


\section{Česká basketbalová účast na půdě NCCA}

Univerzitní basketbal hrají hráči do 25 let. Z českých basketbalistů v minulost působili v NCAA např. Jiří Zídek (UCLA), Luboš Bartoň (Valparaiso), Aleš Chán (Seton Hill a West Virginia) či Petr Burda (Albany). Mezi současné hráče patř́ i dva odchovanci brněnského basketbalu - Marek Souček a Patrik Auda.

Oklahoma State University nastupuje v oranžových barvách školy, která je zařazena do konference Big 12. Patří mezi ty lepší, přestože poslední národní titul získala v roce 1946 . V roce 2004 se dostala až do Final Four. Marek Souček si na základě velmi dobrého hodnocení v rámci Canarias Basketball Academy mohl vybírat z nabídky amerických univerzit a jeho volba padla právě na Oklahoma State. (http://basketbal.cz/).

Další současný hráč NCAA Patrik Auda poté, co se neprosadil v brněnském kádru mužů Mattoni NBL, absolvoval roční působení v basketbalové akademii na Kanárských ostrovech a dnes je v Seton Hall University v New Jersey považován za hráčskou naději. Na soukromé katolické univerzitě může navázat na své slavné předchůdce jako byli Rimantas Kaukenas, Samuele Dalembert či Artūras Karnišovas (http://basketbal.cz/).

NCAA je největší sportovní neziskovou asociací v USA usnadňující studentům-sportovcům vysokoškolské studium v souběhu s výkonnostním sportem. Předpokladem k získání stipendia je dosažení dobrých studijních výsledků. Neméně důležité jsou nadprůměrné sportovní výsledky a dobrá spolupráce s trenéry. Minimální věk pro přijetí do tohoto studijního programu je 18 let, horní hranice je 24 let. Předpokladem je absolvovaná střední škola a znalost anglického jazyka.

\section{LITERATURA}

Bale, J., \& Maguire, J. (1994). The global sports arena: athletic talent migration in an interdependent world. London; United Kingdom: Frank Cass \& Co. Ltd.

Coakley, J. (2001). Sport and Society. Issues and Controversies. New York: Mc-Graw Hill.

Crossan, W. (2012). Sporting immigrants and their effect on sport popularity in a culture: The case in Czech basketball. Dizertační práce. Praha: Karlova univerzita.

Eitzen, S. D. (2006). Fair anf Foul. Beyonf the Myths and Paradoxes of Sport. Third Edition. Mandam: Rowman and Littelefield Publishers, Inc.

Goldiner, D. (2003). Games for the Whole World. U.S. Society and Values, 8(2). Retrieved April 20, 2009, from http://igmlnet.uohyd.ernet.in:8000/InfoUSA/society/ijse1203/goldiner.htm.

Larmer, B. (2005). Operation Yao Ming: The Chinese Sports Empire, American Big Business, and the Making of an NBA Superstar (p. 352). Gotham.

Maguire, J., \& Pearton, R. (2000). The impact of elite labour migration on the identification, selection and development of European soccer players. Journal of Sports Sciences, 18(9), 759-769.

Maguire, J. (2002). Sport and Globalization. Handbook of Sport Studies. London: Sage.

Maguire, J., \& Stead, D. (2005). Cricketers of the Empire. Power and Global Sport. Zones of prestige, emulation and resistence. New York: Routledge.

Maguire \& Falcous, M. (2005). Making touchdowns and hoop dreams. Power and Global Sport. Zones of prestige, emulation and resistence. New York: Routledge.

Sekot, A. (2006). Sociologie sportu. Brno. Paido a Masarykova univerzita.

Yiannakis, A. \& Melnick, M. (2001). Contemporary Issues in Sociology of Sports. Champaign: Human Kinetics.

\section{Internetové zdroje}

http://igmlnet.uohyd.ernet.in:8000/InfoUSA/society/ijse1203/goldiner.htm.

http://cs.wikipedia.org/wiki/NCAA

http://basket.idnes.cz/basketbalove-univerzitni-finale-ncaa-bude-i-na-ceskych-obrazovkach-1 dr-/nba. aspx?c=A080404_115230_nba_kal

http://basketbal.cz/12050-cesi-a-slovaci-za-morem-ze-vsech-uhlu-marek-soucek.html

http://basketbal.cz/8327.html

http://www.sportovnistipendia-usa.cz/af10-ncaa.html 